\title{
MyPetSB - Management system for animals for adoption
}

\author{
Alecsander Dornelles $^{1}$, Rafael Baldiati Parizi ${ }^{1}$ \\ ${ }^{1}$ Farroupilha Federal Institute \\ Otaviano Castilho Mendes Street - São Borja - RS - Brazil \\ alecsander.donelles@aluno.iffar.edu.br, rafael.parizi@iffarroupilha.edu.br
}

\begin{abstract}
The information is generated by thousands of people around the world every second on several devices available in the world. As a result of a conversation with ACOPASB members in the city of São Borja, a large amount of abandoned animals were found on the streets of the city and a large amount of animals were available for adoption. It has also been noted that people use social networks to search for animals for adoption or to inform others of lost and / or abandoned animals. Due to these problems, the present work proposes the development of an information system that will manage animals for adoption in the city of São Borja.
\end{abstract}

\section{Introduction}

Information is increasingly inserted in people's lives because of the rapid technological evolution that occurs every day. Computers, smartphones, connected TVs are just some of the mass comunication ways that the 21 st Century provided to man through technological evolution. With this, a lot of data are generated daily by people from all over the world through various means and ways, which according to [Luz 2010] makes technology as the very history of the human being. This allows people to work, have fun, watch news, study and search for various types of information the internet provides. This makes it easy to see the great importance that technology and information have in people's lives, and yet, the information can be false, decentralized, disorganized, incomplete and / or not up to date, preventing people from making their daily tasks more flexible and making them more difficult due to lack of information in several areas.

According to ACOPASB records, São Borja has demonstrated a large number of abandoned animals on the streets of the city, which is remedied through non-governmental organizations, veterinaryes, pet shops or the community in general that often collect and treat them for later adoption. It has also been noted that people use social networks, such as Facebook, to look for animals for adoption or to inform others of lost and abandoned animals. With this, the information becomes decentralized and difficult to filter for many people.

Due to these several problems, the present work proposes the development of an information system that will control animals for adoption in the city of São Borja. The system will be compatible with several devices, among them computers, smartphones, televisions with Internet access, tablets, notebooks, among others.

From this system, it is hoped to gather information on lost animals, for adoption and abandoned, so that the community of São Borja has a centralized way of obtaining and distributing information about animals. Along with this, it is hoped to reduce the 
difficulty and manual procedures for adopting animals, reducing the number of animals for adoption in organizations and the number of abandoned animals in the streets.

This paper is outlined as follows: Section 2 introduces the concepts about the information technology, information systems and software engineering; Section 3 describes the research study conducted in this paper; Section 4 presents the results of this work, while Section 5 explains the outcomes doing some discussion about them. Section 6 shows a set of related works, and; finally, Section 7 draws the final considerations highlighting important discovers.

\section{Background}

\subsection{Information Technology}

[Pinochet 2014] affirms that the word technology has a Greek origin and means "set of knowledges", which permeates all areas of knowledge, which allows the human being to construct and transform the environment through information in order to satisfy all the essential needs of the men.

According to [Veloso 2011], the increasingly strong and marked presence of such technologies in our society has been suggesting and pointing out various forms of appropriation, aiming at the improvement and improvement of the work.

According to [Lima 2000], the information has a problem which is the lack of proper filtering, which prevents the information from being completely useful. Because of this, [Pinochet 2014] suggests that humans need to learn to forget or discard information that has already been learned or assimilated. Another point to emphasize is the need to organize the information, which, although complete, is presented in different places.

[Araujo 2001] suggests that the great process of adaptation in which modern society is passing may not be easy because of the great social inequality that permeates the means of the spread of technology, making the lives of many people even more distant. In contrast, [Pinochet 2014] states that society needs to rethink the need, utility and meaning for the use of Information and Communication Technologies (ICT), regardless of the social group in which they are inserted, and also need to reconsider the importance of practices inclusion in the contemporary information society.

\subsection{Information Systems}

According to [Oliveira and Costa 2016] the human being is at all times consulting some type of data or information, for example, the weather forecast of some city. In order for this information to be generated, several data were analyzed and related using different information systems.

According to [Baltzan and Phillips 2012], data can be a symbolic representation, without a given meaning, and can take the form of a number, character, sound, figure, symbol. The author suggests that these data are the main raw material of information systems, which allows them to generate information through its powerful processing, ensuring the use of information systems as a tool.

[Oliveira and Costa 2016] says that developing an information system is like building a house, someone can delegate this task to others in the hope that the house will 
meet the needs of several people who have not been directly involved with the building. The author suggests that the development of an information system requires the collaboration of all project stakeholders to ensure that those who are directly connected to the system can use the information correctly. The author states that some elements for the development of an information system may not be available in a clear and objective way and that the search for these elements becomes indispensable through the use of information collection methodologies, in order to guarantee a work orderly, disciplined, and well-planned.

\subsection{Software Engineering}

According to [Wazlawick 2013] the software crisis of 1970 was the trigger for better visualization and organization of software projects. According to [Dijkstra 1971] this crisis occurred because of the great evolution of computing at the general level and the consequence of the high demand of more complex systems for development companies, in which it made the organization of development projects chaotic.

According to [Hirama 2012], software engineering aims at defining a better way of communication between the development team through annotations and documents, thus creating a standardization of the products made by the team, allowing employees to be trained to improve the software quality practices. The author points out that as software is developed some researchers were looking for ways to display these units of software in a graphical way, through flow charts, but this form was eventually depreciated due to the lack of compatibility with complex systems.

[Sommerville 2011] suggests that a system must have descriptions of its functionalities, that is, what it must do, the services it must offer, and restrictions on its functioning, that is, software requirements. These requirements need to be written at different levels for the better management and categorization of its functionalities that the system will have, which, according to the author, generates a better communication between the different stakeholders.

\section{Method and Development}

For the accomplishment of the present work was used a methodology constituted of steps for the better separation and organization of the project itself. The system developed will be used by different types of users, and because of this, the conversations about the daily life of these people was necessary for a better understanding of the real need of functionalities for them.

The first stage of the work (see Subsection 3.1) is focused on the exploratory research that, according to Prodanov et al. [Prodanov and de Freitas 2013], has the purpose of searching for information about the subject under investigation, making possible its definition and its delineation, that is, to facilitate the delimitation of the research theme; to guide the setting of objectives and the formulation of the discover a new kind of focus for the subject. It involves activities such as bibliography, analysis of examples that stimulate understanding and other techniques.

Thus, we performed meetings with stakeholders (see Subsection 3.2); extract the software requirements (see Subsection 3.3); perform database modeling (see Subsection 3.4), and; system development (see Subsection 3.6). 


\subsection{Animal Adoption Systems Research}

The project began with a research of systems for animal adoption in order to understand the current scope of systems of this type, with this research aimed to collect data on possible users, ways to display information, cases of uses used and the best delineation about concepts that are addressed at work.

\subsection{Meetings}

The realization of informal meetings to understand the real needs of users of the system becomes important for the development of the project, because it was at this stage that the data about the needs and about how the tasks in the scope of this work are performed daily were obtained.

\subsection{Requirements gathering}

After the meetings with the responsible professionals, a requirements survey was made to better understand the problems that the system will deal with and to better understand the real needs of potential users of the system, in order to delineate the functional and non-functional requirements that the system will have. Through the data obtained in the meetings with users in the previous stage, it was possible to gather data that aided in the general development of the system, such as the choice of technologies that fit the reality of the project.

\subsection{Database Modelling}

Through the analysis of the data obtained in the requirement survey stage, the database modeling stage was performed using the MYSQL Workbench tool, which allows the developer to create a relational database model and generate the code to create the database. It is expected to satisfy all the modeling needs in this step, so that the system has concise and correct data.

\subsection{Prototyping}

Together with the database modeling was carried out the prototyping stage of the system screens, which allowed the possible users to have a sense of how the system will be ported graphically in different devices and how the data will be displayed to the users, ensuring greater compliance with the requirements.

\subsection{System Development}

After the database modeling and the prototyping, the system development stage was carried out, which have the following technologies and their respective functions.

- Laravel as a PHP framework for the back-end (server side);

- Bootstrap for the development of the front-end (client side), that is, the visual of the pages of the system; and

- $M y S Q L$ for the database;

Using the technologies described above, it was possible to obtain a project with good maintenance and responsive design, allowing several types of devices to have access to it with all its functionalities. Figure 1 shows the system's home page in its normal, responsive version for devices with smaller screens, proving the importance of responsive development, ensuring a larger target audience and allowing the use of native features such as the geolocation of smartphones, a feature that is widely used in this work for the definition of locations containing animals for adoption, abandoned and lost. 


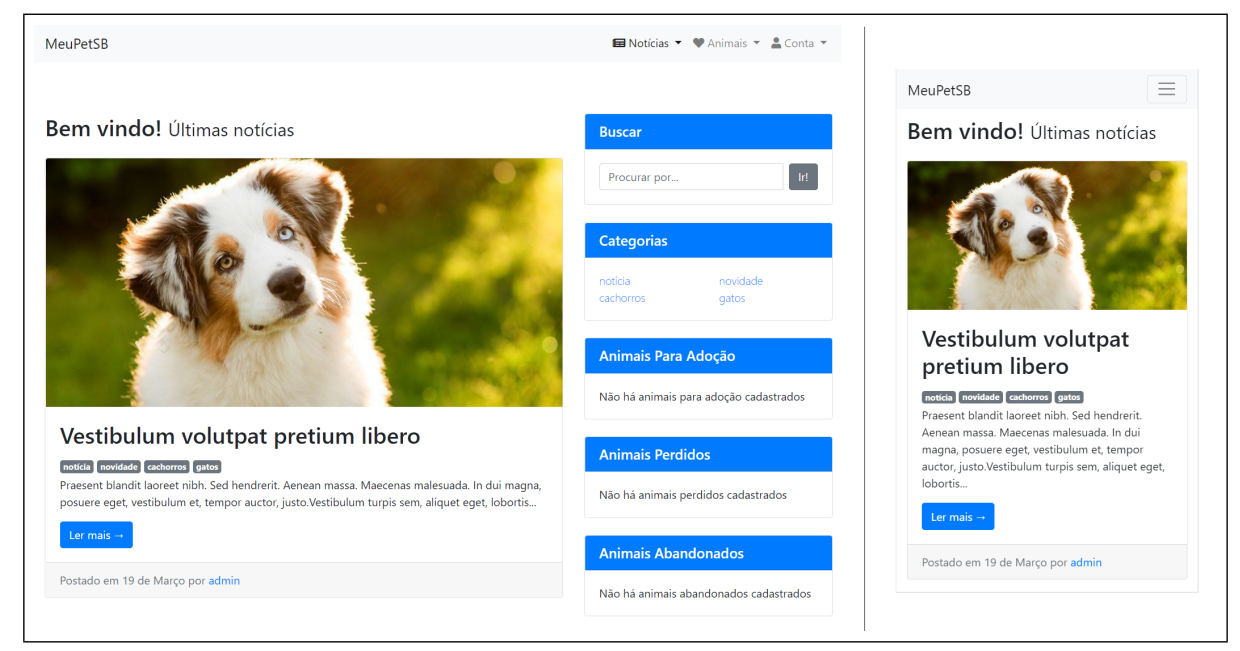

Figure 1. Home page of the project.

\subsection{Tests}

At this stage some tests were performed with the possible users of the system, aiming to guarantee its usability and carried out a survey of information for further improvements.

\subsection{Code Refactoring}

After the code analysis, the refactoring step was performed to improve the quality and performance of the system. This stage is important due to the technical evolution that took place during its development and also by the gain of experience using the technology, guaranteeing an evolution in the part of the code and the developer.

\subsection{Documentation Creation}

After completing the development and testing stages of the system, the documentation was created. This documentation is separated into documentation for ordinary users and for administrative users, aiming at their better organization and understanding by their users. The documentation can be seen in Figure 2.

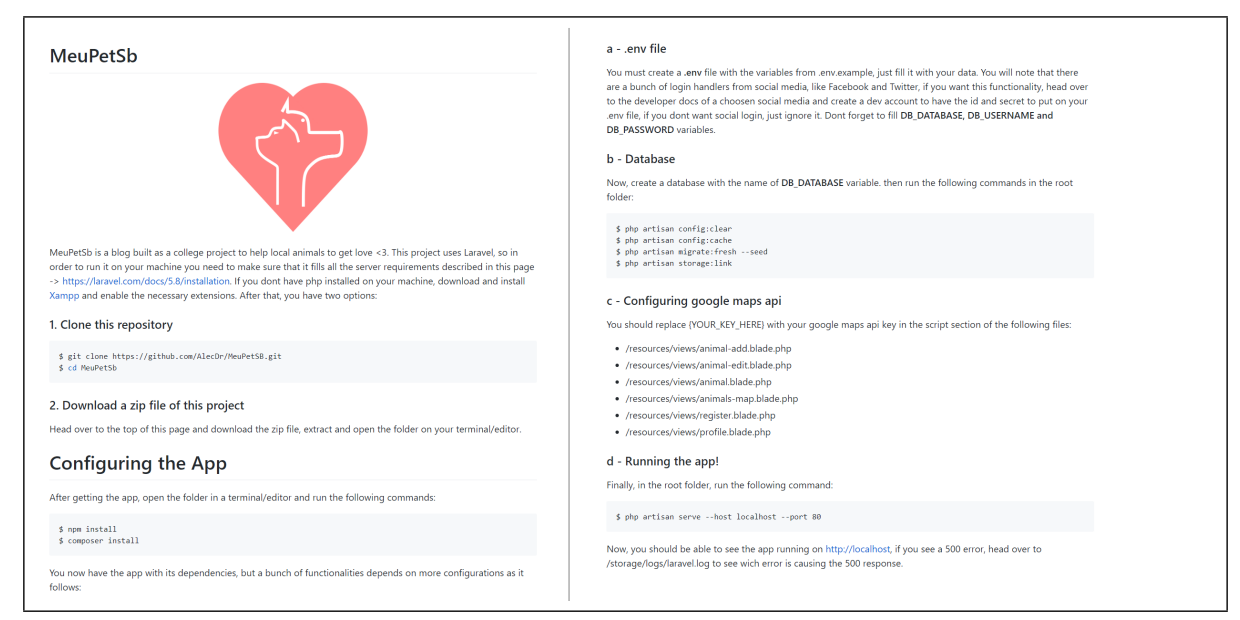

Figure 2. Documentation generated to the project. 


\section{Findings}

During the development of this work happened the discovery of information on lost, abandoned and adopted animals in the city of São Borja, which will be made available by the system and in the future it may help the administration of the city of São Borja to better plan for abandoned animals in their streets, investing more and providing a more appropriate and safe place for the retrieved animals, in which it can avoid in the growth of zoonoses.

Also, the technological and social learning acquired during the development of the work was very positive because, through those and through tests and studies on technologies, it was possible to better understand the real problems faced by those involved with animals. The features raised through conversations with experts in the field required a cautious filtering of technologies to be used, since the system to be working was not the only delimiter to be followed. Along with it, performance, safety and responsiveness were goals to be achieved to ensure the satisfaction of users who will use it. Through video tests it was possible to understand the positives and negatives of the system in a quick and pragmatic way, because once the video has been sent, the user could visualize it as many times as he / she wanted and palpitate on the important points for the system. Something important for the system and also for learning was the realization of a visual for the system.

This work showed a possible solution to reduce the number of abandoned animals, animals for adoption and to facilitate the finding of animals lost in the city of São Borja through a easy to use web responsive system, capable of being accessed by many devices with access to the internet.

\section{Discussion}

This work presented a web information system aimed at the community of São Borja, focusing on the improvement and centralization of information about animals for adoption, lost animals and abandoned animals.

To achieve these objectives, research was done on existing animal systems for adoption, bibliographic research and studies on relevant subjects such as programming languages and information and communication technology and databases The technologies chosen to develop the system are free, thus guaranteeing a low cost and good quality development.

The work began with a research on existing systems on animals for adoption, after this, discussions were held with animal professionals to understand the daily problems and ways of remedying these problems, allowing a flexibility of ideas and the formation of fundamental concepts for the development of this work. With the analysis of the data collected with the conversations, a survey was made of the requirements to define the functionalities that the system will have, allowing a better visualization of these through use case diagrams. The modeling of the database took place through the analysis of the data generated in the requirement survey step, because it was through these data that it was possible to understand the models needed to represent the information that will be present in the system, this process was done using Mysql Workbench because the system uses a Mysql database. After knowing what information the system will show, the prototyping 
stage of screens started, that gave an idea of how the information will be available in different devices, because as said before, the proposed system is responsive.

\section{Related work}

According to [Castells 2001], the internet is one of the first forms of mass communication, that is, many to many, and this enabled the great universe of information that we have today. Because of this, the information needs to be organized to meet the diverse needs. With this, [Stair and Reynolds 2006] inform that information systems are sets of integrated and independent parts, but with common goals in computational means, which verifies the real importance of software that informs users about a certain subject.

According to [Luz 2010], groups of people tend to use information dissemination and information gathering techniques through news features, dynamic content and reports, and with these characteristics humans organize the information in a more concise way.

It is also important to highlight the importance of mobile web, which has been gaining strength in recent years and enabling many people who did not have access to the internet to access it through these new devices. According to [Lopes 2014], there is no Web mobile, only the Web, which is accessed from computers, tablets or cell phones, all of which run on the same languages, such as HTML (Hypertext Markup Language) CSS (Cascading Style Sheets) and Javascript, regardless of the device. This allows a computergenerated code to run seamlessly on any device with internet access, but not guaranteeing the same usability on these various devices.

It is a good strategy to start with a web system, to ensure presence in the market and society, given the fact that the web is intrinsic in the current world due to the various devices with access to the web [Lopes 2014].

Systems for animal adoption are not new, big names such as [ArcaBrasil 2018], [Vivalocal 2018] and [Mapaa 2018] already have systems for animal adoption, but none of them has a good coverage in each city, for factors such as lack of research on the actual needs in each city where they are applied, lack of animal information and in some cases allow users to sell animals. Most of these systems have animals for adoption in several cities of the country, making it difficult to obtain these animals that can be in any city of Brazil.

\section{Final considerations}

In the future it is expected to carry out more tests with a greater selection of users to test all types of users and thus guarantee a harmony between them. It is also expected to add more features according to the needs of these users before testing. Something also thought for the future is the possibility of registering a new lost animal that has an area, a warning for all users registered within the area to be fired, increasing the ease of receiving and consuming information and also helping to find these animals . It is also expected to use an automated form of detection of sale of animals or register of offensive words, which is done manually by admin users, taking time and attention of these and becoming a difficult task. 


\section{References}

Araujo, L. C. G. (2001). Tecnologias de gestão organizacional. Atlas, São Paulo, SP, Brasil.

ArcaBrasil (2018). Arca brasil, proteção e bem-estar animal.

Baltzan, P. and Phillips, A. (2012). Sistemas de informação. AMGH, Porto Alegre, RS, Brasil.

Castells, M. (2001). A galáxia internet: Reflexões sobre a internet, negócios e a sociedade. Zahar, Brasil.

Dijkstra, E. W. (1971). The Humble Programmer: Communications of the ACM.

Hirama, K. (2012). Engenharia de Software: Qualidade e Produtividade com Tecnologia. Elsevier Editora Ltda, Rio de Janeiro, RJ, Brasil.

Lima, F. O. (2000). A sociedade digital: Impacto da tecnologia na sociedade, na cultura, na educação e nas organizações. Qualitymark, Rio de Janeiro, RJ, Brasil.

Lopes, S. (2014). A Web Mobile: Programe para um mundo de muitos dispositivos. Casa do Código, São Paulo, SP, Brasil.

Luz, C. (2010). Arquivologiaa 2.0: A informação digital humana. Bookess Editora, Florianópolis, SC, Brasil.

Mapaa, I. (2018). Instituto mapaa - trabalhando pelo bem-estar e pelos direitos dos animais ainda a serem conquistados.

Oliveira, R. F. and Costa, L. A. A. (2016). Sistemas de computação e de informação. Educacional S.A, Londrina, PR, Brasil.

Pinochet, L. (2014). Tecnologia da informação e comunicação. Elsevier Editora Ltda, Rio de Janeiro, RJ, Brasil.

Prodanov, C. C. and de Freitas, E. C. (2013). Metodologia do trabalho científico: métodos e técnicas da pesquisa e do trabalho acadêmico-2 ${ }^{a}$ Edição. Editora Feevale.

Sommerville, I. (2011). Engenharia de Software. Pearson, São Paulo, SP, Brasil.

Stair, R. M. and Reynolds, G. W. (2006). Princípios de sistemas de informação: uma abordagem gerencial. Pioneira Thomson Learning, São Paulo, SP, Brasil.

Veloso, R. (2011). Tecnologias da Informação e da comunicação: desafios e perspectivas. Saraiva, São Paulo, SP, Brasil.

Vivalocal (2018). Classificados - anúncios grátis - vivalocal.

Wazlawick, R. S. (2013). Engenharia de Software: Conceitos e Práticas. Elsevier Editora Ltda, Rio de Janeiro, RJ, Brasil. 